\title{
Introduction: secular criticism and the politics of studying Islam
}

\author{
By Peter P. Mandaville
}

In recent years many within the European and North American academies whose research engages topics and themes that encompass the study of Islam and Muslim societies have found not only that their subject matter has become the object of frequent and often intense public debate, but also that their scholarship — indeed their very vocation - seems likewise under considerable scrutiny. The public dimension here is important. We are not concerned with a disagreement over the finer points of social theory between otherwise amiable colleagues that plays out through the pages of an obscure academic journal. Rather, we are talking about a state of affairs that has threatened careers and livelihoods, funding streams, and the fundamental basis of academic freedom.

At the outset, it is important to point out that there is nothing exceptional about the politicization of scholarship or the study of Muslims in particular. Academics working in intellectual traditions such as Marxist social theory were frequent targets of public suspicion during the Cold War. What this past situation shares in common with the current debate is, in fact, highly illustrative of the core dynamics at work today: in both cases we are dealing with scholars working on topics or within an intellectual tradition that policy and popular discourse (of course the two are always crucially intertwined) have defined as a 'problem' - and, more specifically, a problem accompanied by considerable danger, threat, and risk. The study of Islam and Muslims thus has not only become politicized, it has also become 'securitized.' Of course, there are certain important points of contrast that need to be drawn with the Cold War experience. For example, the politicization of Islam today transcends conventional division of the political spectrum. Conservative ideologues see in Islam not only security risks (and, in the American debate, the threat of 'Islamo-fascism'), while real fascists further to the right see Muslims in terms of the immigrant others. For those on the political left, conversely, Islam represents a threat to progressive norms on gender and sexuality, and - more widely - to pluralism and liberal tolerance. 
The different historical experiences and engagements with Islam and Muslim immigration in Europe and North America have meant that the debate and surrounding academic politics have played out somewhat differently on both sides of the Atlantic. In the case of the United States, for example, the 'problem' arising from Islam has come to be defined almost exclusively in terms of terrorism and security. Many of the responses to scholarship in this area - such as Daniel Pipes' notorious Campus Watch and the proposal for national security oversight of federal research grants to higher education-have hence focused on the fact that academic experts have supposedly failed to perceive (or worse, deliberately downplayed) the threat posed by Islam. The presence of increasing numbers of Muslims in Europe, however, includes but also goes well beyond questions of terrorism. In Europe, Islam is embroiled in larger debates about immigration and about the limits and future of the liberal nation-state. In other words, within the European debate, Muslims are seen not just to posit a potential existential threat in the physical sense, but also to represent a challenge to Europe as a cultural project. Thus we can say that Islam does not create, but rather throws into relief (...or helps us offload?) a much deeper set of ambivalences that relate to the nature and meaning of European identity, and which have been brewing long before Muslims became a 'problem.'

The contributions to this special issue of the FIFO journal engage and explore various dimensions of the recent politicization of scholarship on Islam and Muslims in Europe. Sharing a common set of concerns, but departing from different disciplinary perspectives and with varying goals in mind, these papers offer important insights into the political, methodological, and pedagogical dimensions of the present debate. Garbi Schmidt's contribution raises some of the dilemmas posed to researchers (and their subjects) when scholarship is commissioned by or receives government sponsorship. Her analysis, however, goes beyond issues of, for example, research ethics and asks us to consider the sociology that lies behind the public consumption of research and expert knowledge. Invoking Ulrich Beck's concept of risk society, Schmidt points out that, increasingly, research is valued only when it can provide clear and incontrovertible (preferably quantifiable) 'facts' about the dangers we face. As she puts it, "the risk that we moderns face in daily life, whether we are dealing with toxic waste or terrorism, raises the demand for facts. 
We want to know what is in our food, what is in the air, and what the nature of Islamism is all about." In the reflexive society, of course, the nature of expertise naturally quickly comes to be defined in terms of whether the appropriate 'facts' and data (devoid of bothersome equivocation or complexity) are being provided, rather than by reference to the credentials, experience, or methods employed by the relevant experts. In the age of new media, of course, the very status and social location of 'expertise' comes into question. News-savvy bloggers dispensing pithy analyses of Danish cartoons or Hizbullah's latest communiqué can easily trump the cumbersome discourse of the PhD-credentialed scholar of Islamic Studies. Schmidt realizes that we are past a point where a claim to unique or exclusive authority in the answers given by academic experts to matters of public concern. Instead she suggests that academe might more profitably offer its critical insight to the formulation of research agendas. "Rather than seeking to answer these questions (and often appearing naïve and defensive)," she writes, "we could make one basic task of our project designs to ask ourselves whether such questions are at all relevant. Is the society around us actually asking the right questions in order to understand the processes...it encompasses?"

In her plea for methodological relativism, Christine Jacobsen also raises important questions about the nature and status of expert knowledge. She points out that research interests and resources are naturally drawn towards subject matters already defined as a 'social problem,' with a concomitant preference for solutionist approaches focusing on the supposed facts of social reality. Pointing to the intimate relationship between knowledge and power, she argues that no neutral vantage point from which to observe and pronounce objectively on social reality exists. Instead, she asks for "a more thorough discussion of the relationship between knowledge and power - a discussion that brings all positions into the social field, rather than establishing some as 'points from nowhere' from [which] to criticize others." Among the more incisive points she provides is the observation that the rhetoric of critics of "relativism" (the most common charge leveled against scholars who refuse to flag 'Islamic' beliefs and practices as abhorrent to liberalism) serves to obscure the existence of highly pluralistic understandings of the very values they claim to uphold. "Liberal notions such as democracy, gender equality, tolerance and 
individual rights," she points out, "[are] defended by taking their content for granted rather than by acknowledging their contestedness and the tensions and nuances in the historical understandings and attempts to implement these notions." Drawing on Andreas Wimmer and Nina Glick Schiller's well-known critique of 'methodological nationalism,' Jacobsen interpolates the popular complaint of 'moral relativism' in the present debate by advocating the utility of an approach she terms 'methodological relativism.' Central to this proposition is the idea that there is considerable heuristic value to be found in the temporary suspension (rather than the wholesale abandonment) of judgment on the part of the social researcher. Like Schmidt, she also calls our attention to the important question of how particular frameworks of analysis (i.e. "questions") force us to render knowledge of the 'other' in particular and often limiting ways.

Drawing attention to the pedagogical possibilities inherent in the current public discussion of scholarship on Islam, Thomas Hoffman invites academics to avoid becoming caught in the 'friend-enemy' dialectic by refusing antagonistic framings of the issues at hand. Inspired by Gerald Graff's noted work on the American culture wars, he seeks instead to reinvigorate agonism as a mode of discursive engagement that does not seek the final resolution of contested ideas-resulting in one side's 'victory' and entailing the vanquishing, erasure, or 'death' of the other-but which instead celebrates the value to be found in an ongoing dialogical coexistence. Translated into a strategy for the present, Hoffman suggests that we neither avoid the politics (it goes with the turf, he points out) nor stake ourselves so completely on one side of the debate. Rather, he suggests, we should employ a strategy of teaching the conflicts: "Part of the solution," he writes, "is...that we try to tease out — and teach out — the sore issues, acknowledge the conflicts and the issues at stake, in short all of the suppressed materials, and then talk/argue ourselves into some kind of heightened understanding and mutual scholarly recognitionwhich should not be interpreted as sheer harmony and agreement, but harmony in discord, conflictual consensus, as it were. Otherwise, researchers, students, media, and the public will be prone to disseminate hostile myths and half-truths about one another or, at least more than hitherto done." There is undoubted value in this, the ultimate reflexive move - a strategy that sees in this debate an opportunity for learning through critical self- 
analysis. Of course, one would hope that the agonistic impulse is reciprocated by a everyone in the conversations - for in the rock, scissors, and paper "game" of research funding, tenure, and public reputation, antagonism often trumps agonism.

In the present climate, we would perhaps do well to remember the late Edward Said's valorization of what he termed 'secular criticism' - referring to the responsibility of public intellectuals to stand apart (in the conventional sense of secularism) not only from religion, but also to maintain a critical distance from other political, nationalist, ideological — and even critical theoretical—projects. Here we find Said turning the postmodern turn on its head by, to some extent, refiguring deconstructionism itself as a form of metanarrative. Christine Jacobsen would undoubtedly see echoes of her methodological relativism in Said's proposition. His is a position that requires the publicly engaged scholar not only to keep a distance from the statist agendas of policymakers, but also to avoid allowing the representation of his or her subject matter to be subjugated to the conceptual schemas of a single methodological or theoretical account of the world. Secular criticism of Islam, Muslims, or any other topic for that matter, is not easy. The secular critic is prodded and pressured - by the academy and the government ministry alike - precisely because of the refusal to play analytical reductionism. Yet this position, highly agonistic and nothing if not methodologically relative, is simultaneously empowering for the very reason if its refusal to by captured by any monological worldview.

The present political climate around Islam will one day, by the very nature of meteorology, recede, blow over - or, more likely, drift over to occupy the sky over another cluster of public 'problems.' It is too early yet to discern whether what some bureaucrats have declared to be a 'long war' against terrorism will assume the enduring characteristics of an entrenched othering of Islam. While we might on the one had yearn for the day when a Muslim on the streets of Europe cuts a banal figure, that is precisely the moment when we must ask ourselves what else has been forgotten in the process of forgetting the present impasse. It is a question that scholarship is uniquely obliged - and thoroughly equipped-to ask. 
Peter P. Mandaville is Associate Professor and Co-Director of Center for Global Studies, George Mason University, Washington. His publications include Global Political Islam (London: Routledge, 2007). Other books include Transnational Muslim Politics: Reimagining the Umma (London: Routledge, 2001; paperback 2003), and several co-edited volumes and anthologies such as Globalizing Religions (London: Sage, forthcoming 2007), The Zen of International Relations (London: Palgrave 2001) and Meaning and International Relations (London: Routledge, 2003). 